\title{
Actio Pauliana as the Rights Protection Efforts for Creditors in the Bankruptcy Case
}

\author{
Puja Dwi Pangestu ${ }^{1}$ \\ ${ }^{1}$ Broto Hastono \& Associates \\ Received April 04 2018, Accepted April 27 2019, Published May 312019 \\ DOI 10.15294/jg.v16i1.18673
}

\begin{abstract}
The implementation of a debt agreement is often found in bad faith by the debtor where the debtor is unable to pay off his debts. When the debtor is deemed unable to pay off all of his debt, the debtor can voluntarily submit palitit to the Commercial Court. Submission of bankruptcy can also be applied by creditors, of course, bankruptcy permits by debtors or creditors must fulfill the conditions mandated in the bankruptcy law. When debtors are declared bankrupt, all assets owned by the debtor are collateral for their debts. However, in its implementation, it is often found that ill will is carried out by the debtor, namely when the debtor feels that he is no longer able to repay his debts, the debtor transfers his assets to the third party for his own benefit. To protect the interests of each creditor then curator can make an action with actio pauliana, , Actio Pauliana is cancellation of all of the legal action of the assets taken by debtors. The research objective of this article is to know and understand the bankruptcy determination process based on the Bankruptcy Act and how actio pauliana attempts to protect the rights of each creditor.
\end{abstract}

Keyword: Debt Agreement; Bankruptcy; Actio Pauliana

\section{INTRODUCTION}

Based on the law that applies if a person or legal subject commits a legal act then it will occur due to the law. It can be analogized when a person or legal entity has bound itself to a credit agreement, so that the legal action creates legal consequences in the form of rights and obligations between the debtor and the creditor or can be referred to as performance in the form of payment of debt.

But in its implementation, sometimes someone in the credit agreement of the debtor is negligent in fulfilling his performance; of course this has violated applicable legal norms. Based on Article 1234 of the Civil Code that "each engagement is to give something, do something, or not do something". With the existence of the article when the debtor has bound himself with the creditor in a credit agreement, the debtor has an obligation to pay off the credit. But in practice often found bad credit that occurs from a credit agreement.

In overcoming this condition, the right step to resolve the bad credit, both for the interests of the Debtor and Creditors. In this case the solution or step that must be taken must provide optimal value for both parties. Many steps can be taken to overcome these problems. The way is by submitting a bankruptcy application. Bankruptcy is a process whereby a Debtor who has financial difficulties to pay his debt is declared bankrupt by the court which in this case is a commercial court because the Debtor cannot pay his debts anymore. ${ }^{1}$ Article 1 paragraph (1) of the Bankruptcy and PKPU Law states that "bankruptcy is the general seizure of all Bankrupt Debtor assets whose management and settlement is carried out by the curator under the supervision of the Supervisory Judge as stipulated in this law". Furthermore, Article 2 paragraph (1) of the Bankruptcy and PKPU Act stipulates that: "Debtors that have two or more creditors and do not pay off at least one debt that has matured and can be billed, are declared bankrupt with a court decision, both on their own request and on request one or more creditors ". In the article referred to as creditor, it is a concurrent creditor, preferred creditor and

1 Nating, Imran. (2005). Peranan dan Tanggung Jawab Kurator Dalam Pengurusan dan Pemberesan Harta Pailit. Jakarta: Edisi Revisi. Cet. 2, PT. RajaGrafindo Persada 
separatist creditor

However, it is very unfortunate that the practice of bankruptcy and PKPU law is often found in the practices of debtors who reflect bad faith; of course this will affect the threat of the rights of each creditor. Poor intentions that are often carried out by debtors in the form of hiding assets owned by the debtor for the benefit of the debtor. The concealment of these assets is carried out by transferring assets or assets before the debtor is declared bankrupt to another party. In the Bankruptcy Law and PKPU, an effort is made to protect each creditor due to the bad behaviour of the debtor.

One of the safeguards against the interests of creditors in the Bankruptcy Act is to prevent fraud committed by debtors. Fraud that can be done by a debtor, for example, a person who has the intention not to make as much debt as possible to subsequently file a bankruptcy statement so as not to pay the debts by first hiding his wealth ${ }^{2}$. The effort was actio pauliana. Actio pauliana is a means provided by the law to each creditor to submit a cancellation of all non-compulsory actions that have been carried out by the debtor where the act has harmed the creditor ${ }^{3}$. Actio pauliana is a right that is owned by creditors in certain circumstances can view null and void actions that have been done by the debtor that harm them ${ }^{4}$. Provisions regarding actio pauliana efforts have been stipulated in article 41 of the Bankruptcy and PKPU Law and article 1341 of the Civil Code.

\section{RESEARCH METHOD}

The research objective of this paper is to know and understand the bankruptcy determination process based on the Bankruptcy Act and how actio pauliana attempts to protect the rights of each creditor. The type of research used is normative legal research because it is in the form of a positive legal inventory, efforts to find positive legal principles and philosophy, and also an attempt to find inconcreto law that is suitable for use in solving a particular case ${ }^{5}$. Legal material collection techniques by conducting library studies by collecting documents relating to legal issues.

\section{RESULT AND DISCUSSION}

In general, bankruptcy is a legal public confiscation of all Debtor property in order to achieve peace between the Debtor and the Creditors or so that the property can be shared fairly among the Creditors. In this case the seizure was carried out by the Court and then the execution of all of the Debitor's assets was carried out for the mutual benefit of the Creditors.

The occurrence of bankruptcy is due to a relationship between creditors and debtors in a credit agreement, where the debtor is considered unable to pay off his debts. So when this happens, the creditor can file a bankruptcy request against the debtor.

The principle of paritas creditorium implies that all debtor's assets, whether in the form of movable or immovable property or property which the debtor has now and possessed in the future, will be owned by the debtor, tied to the settlement of debtor's obligations (Kartini, 2001: 168). In a relationship of legal debts, the law provides legal protection to the board through the provisions of Article 1131 of the Civil Code which determine: "all debt material, both movable and immovable, both existing and new ones will be there later, be borne by all of its commitments ". The provisions of the Article mean when someone has a debt, then the assets of the debtor become guaranteed for their debts.

Further elaborated in Article 1132 of the Civil Code states that: "the material becomes a guarantee together for all those who affirm it; the sales revenue of these objects is according to the balance, which is according to the size of each receivable, except if there are reasons for the said priority. "In this article each creditor has the same position. The position of the creditor, among fellow creditors to the debtor is the same. They are called concurrent creditors and get general guarantees ${ }^{6}$. The most important requirements for debtors to be declared bankrupt have been fulfilled, namely having two or more creditors and debts that are due and can be billed. In Article 2 paragraph (1) Law no. 37 of 2004 concerning Bankruptcy and PKPU stated that: "Article 2 paragraph (1) Law No. 37 of 2004, a Debtor who has two or more Creditors and does not pay in full at least one debt that has matured and can be billed, is declared bankrupt with a court decision, both on his own application and on

2 Anisah, Siti. (2009). Perlindungan Terhadap Kepentingan Kreditor Melalui Actio Pauliana, Jurnal Hukum No. 2, Vol. 16, 205-221, p 205

3 Syahrin, M. Alvi. (2017). Actio Pauliana: Konsep Hukum dan Problematikanya. Jurnal Lex Librum, Vol. IV, No. 1, Desember 2017, hal. 605 - 616. http://doi.org/10.5281/zenodo.1257787

4 Sofwan, S. S. (1975). Hukum perdata: Hukum Perundangan. Bag 8, Liberty, p 39

5 Adi Rianto. (2004). Metodologi Penelitian Sosial dan Hukum. Jakarta: Granit, p 92

6 Satrio, J (1997). Hukum Jaminan, Hak Jaminan Kebendaan, Hak Tanggungan, Buku I, Citra Aditya Bakti, Bandung, p 54 
the request of one or more Creditors “.

Provisions of Article 3 of Law No. 37 of 2004 concerning Bankruptcy and PKPU that "Debtors who have two or more Creditors and do not pay off at least one debt that has matured and can be billed, are declared bankrupt with a Court decision, both on their own application and on the request of one or more Creditors".

Based on the description of Article 2 and Article 3 of the Act on Bank PKPU, it can be concluded that the terms of the debtor can be declared bankrupt, including: (1) The existence of debt; (2) There are two or more debts; (3) At least one debt has matured and can be collected; (4) Determination of Bankrupt Debtors is issued by a special court called the Commercial Court; (5) Bankruptcy applications are submitted by the Debtor itself, one or more Creditors, Prosecutors for Public Interest, Bank Indonesia if the Debtor is a Bank, BAPEPAM if the Debtor is a Securities Company, and the Minister of Finance if the Debtor is an Insurance Company; (6) If the conditions are fulfilled, "The judge declares bankruptcy", and cannot be declared bankrupt. So that in this case the Judge is not given space to give a broad "judgment" as in other cases, in fact limited defense is still justified considering the validity procedure that concludes with the provisions of Article 8 paragraph (4) of the Law Bankruptcy and PKPU.

When the judge has established a bankrupt debtor, all the good assets that already exist and which will be there will be controlled by the curator for the purpose of repaying all receivables from the creditor. Bankruptcy decisions bring legal consequences to all debtor assets. The wealth will be controlled by the curator. It is the curator who will take care and clean up all the bankrupt assets. As a result of the bankruptcy decision it has the consequence that legal claims originating from the rights and obligations of the bankrupt debtor's assets must be filed by or against the curator. If the claim is submitted or forwarded by or against the bankrupt debtor, then if the claim results in the punishment of the bankrupt debtor ${ }^{7}$.

Based on Article 24 of the Bankruptcy and PKPU Law, the consequences of debtors declared bankrupt are as follows: (1) Debtors legally lose their rights to control and manage their assets included in bankrupt assets, from the date the bankruptcy statement is pronounced; (2) The date of the decision referred to in paragraph (1) is calculated from 00.00 local time; (3) In the event that before the decision on a bankruptcy statement is stated that a transfer of funds has been carried out through a bank or institution other than a bank on the date of the decision, the transfer must be continued; (4) In the event that before the decision on a bankruptcy statement is stated that a Securities Transaction has been carried out at the Stock Exchange, the transaction must be completed. .

Based on Article 24 of the Bankruptcy Act and PKPU above, it is explained that when a debtor is declared bankrupt, the item does not have the right to control all of their assets, both immovable movable assets, existing and existing assets. By establishing a bankrupt debtor, the assets become court confiscated goods and the court appoints a curator to settle the debtor's receivables by being supervised by the supervisory judge.

However, in the implementation of bankruptcy, it is often found that the debtors did not have good intentions. Often the debtor protects the assets owned for his own benefit, the debtor carries out legal actions that are not updated by law. To protect its assets from bankruptcy, the debtor transfers assets to other assets either through buying and selling or transferring the names of assets owned to other parties. The effort was carried out in the hope that the assets owned would not become collateral for its debts. These efforts are often referred to as actio pauliana carried out by curators.

This is a logical consequence of the position of the Curator as the party whose duty is to protect and manage bankrupt assets for the benefit of all parties concerned with bankrupt assets. ${ }^{8}$

With the lack of willingness from the debtor to protect the rights of creditors in article 41 of the Bankruptcy and PKPU Laws it is stated that:

"(1) For the purpose of bankrupt assets, the Court may ask for cancellation of any legal acts of the Debtor that have been declared bankrupt which are detrimental to the interests of the Creditors, which are carried out before the decision of the bankruptcy statement is pronounced;

(2) The cancellation as referred to in paragraph (1) can only be done if it can be proven that at the time the legal act was carried out, the Debtor and the party with whom the legal action was conducted knew or duly knew that the legal action would cause losses to the Creditors;

(3) Excluded from the provisions referred to in paragraph (1) are Debtor legal actions which are obliged to be carried out based on the agreement and / or because of the law. "

7 Sunarmi. ( 2010). Hukum Kepailitan. Jakarta: Edisi 2, Sofmedia, p 10

8 Sukirno, T. (2001). Tanggung Jawab Kurator Terhadap Harta Pailit dan Penerapan Actio Pauliana. Bandung: Alumni, p 371-372 
Furthermore, Article 42 of the Bankruptcy and PKPU Law states that if a legal action that harms a creditor is carried out within a period of 1 (one) year before the decision on a bankruptcy statement is stated, the Debtor does not have to prove it otherwise, the Debtor and the party the act carried out is deemed to know or appropriately know that the act will cause harm to the creditor as referred to in Article 41 paragraph (2).

In the case of filing actio pauliana submitted by the curator for the benefit of the creditors, the submission of actio pauliana is intended to mention all legal acts of the debtor which are not permitted under the law on all wealth assets. The later the assets become collateral for debts from the debtor. In accordance with articles 41 and 42 when actio pauliana is granted by a judge, the legal action on nutrient and assets is canceled a year before the bankruptcy decision is pronounced.

\section{CONCLUSION}

A legal action must create legal consequences for each legal object, one of which is when a person enters into a credit agreement, rights and liabilities will arise between the creditor and the debtor. When a debtor is unable to fulfill his obligations, the debtor can be declared defaulted. In the case of a debt agreement when the debtor is deemed unable to repay his debt, the debtor can be declared bankrupt if he meets the requirements mandated by law and is based on a court decision.

However, when it was declared bankrupt in reality, it was still found to be unfavorable in the faith of the debtor, where the debtor transferred his wealth to third parties for his own interests. Based on the Kepilitan and PKPU Act, the curator can cancel the legal deeds of the debtor for one year before the bankruptcy decision from the court, through the actio pauliana.

Suggestions that the author submits are: (1) In implementing the agreement, it is expected that each party can carry out its rights and obligations in accordance with the agreed agreement and applicable laws; (2) The debtor at the time has been declared a default will prioritize goodwill towards the creditor for his debts; (3) When the debtor is deemed unable to repay his debts, the debtor can file a bankruptcy application, and when the debtor is declared bankrupt by the court, it is expected that the assets will not be transferred to joint interests; (4) The curator in charge of supervising the supervising judge must be observant of the assets of the debtor and be sure to determine the creditors of the debtor; (5) The curator must be observant of legal actions carried out by the debtor for assets owned for one year after the debtor is declared bankrupt.

\section{BIBLIOGRAFI}

Anisah, Siti. (2009). Perlindungan Terhadap Kepentingan Kreditor Melalui Actio Pauliana, Jurnal Hukum, 17(2):205-221.

Kartini Mulyadi, (2001), Kepailitan dan Penyelesaian Utang Piutang dalam Rudhy A. Lontoh (ed), Penyelesaian Utang Piutang Melalui Pailit atau Penundaan Kewajiban Pembayaran Utang, Alumni, Bandung.

Nating, Imran. (2005). Peranan dan Tanggung Jawab Kurator Dalam Pengurusan dan Pemberesan Harta Pailit. Jakarta: Edisi Revisi. Cet. 2, PT. RajaGrafindo Persada

Rianto, Adi. (2004). Metodologi Penelitian Sosial dan Hukum. Jakarta: Granit.

Sofwan, S. S. (1975). Hukum perdata: Hukum Perundangan . Bag 8, Liberty

Sukirno, T. (2001). Tanggung Jawab Kurator Terhadap Harta Pailit dan Penerapan Actio Pauliana. Bandung: Alumni

Sunarmi. ( 2010). Hukum Kepailitan. Jakarta: Edisi 2, Sofmedia.

Syahrin, M. Alvi. (2017). Actio Pauliana: Konsep Hukum dan Problematikanya. Jurnal Lex Librum, 4(1):605 - 616. http://doi. org/10.5281/zenodo. 1257787

Satrio, J (1997). Hukum Jaminan, Hak Jaminan Kebendaan, Hak Tanggungan, Buku I, Citra Aditya Bakti, Bandung.

Tamba, F. R. (2017). Analisis Putusan Pailit Nomor: 02/pailit/2009/pn. niaga. smg terhadap Undang-undang Nomor 37 Tahun 2004 Tentang Kepailitan dan Penundaan Kewajiban Pembayaran Utang. Journal of Private and Commercial Law, 1(1). 